\title{
The Relevance of Place-Brand Management in Place-Marketing Strategy*
}

\author{
Andrea Moretta Tartaglione, Roberto Bruni \\ University of Cassino and Southern Lazio, Cassino (FR), Italy
}

\begin{abstract}
Observers perceive each place through a particular image, not necessarily positive, definable in a distinctive positioning through place-marketing strategies; the relations between the actors of the territory system play an important role, and the place-brand becomes "the connector" of the relational network in place-marketing management. The aims of this article are to analyze the relations between place identity, place-brand, and place-marketing strategy; to look at case studies of bottom-up strategy as a medium for the long-term empowerment of the place-brand strategy; and to examine the relevance of place-brand positioning and interaction between governance and stakeholders in place-marketing strategy development.
\end{abstract}

Keywords: place-marketing, place management, place-brand, network, value generation, strategy

\section{Methodology}

The work is theoretical and based on the place-brand literature: It refers to the role of this construct in the place-marketing strategy, to the positioning concept, and its construction over time.

We decided to carry out a survey of the relevant literature, underlining the importance of the connection between studies of place-marketing and place-brand, and to perform a qualitative simulation to reduce the complexity emerging among the elements that insist on the nature and definition of place-brand positioning and on their relevance to the construction of the place-brand value. Specifically, beginning from some definitions of place image and place identity, we assign effect multipliers-positive or negative with respect to the positioning of the place-brand - to marketing strategies and a scalar multiple to the size of the territory which is developed through the marketing and place-brand. These concepts are summarized in the graph of the simulation (see Figure 3 ) and in the formula $P B P=(P I / V T) \cdot M S$.

\section{Marketing and Strategy in Place Development: References to the Literature}

Studies of place-marketing continue to interest many researchers on the international level on account of the multidisciplinary aspect of its scope. As a matter of fact, because of the growing relevance of the value of territories, the topic lays out an interesting path toward alternative models of territory development which are

\footnotetext{
* The article is the result of a joint effort: Andrea Moretta Tartaglione is the author of sections 1, 2, 3, and 6; Roberto Bruni wrote sections 4 and 5.

Andrea Moretta Tartaglione, Assistant Professor in Business Management, Department of Economy and Law, University of Cassino and Southern Lazio.

Roberto Bruni, Research Fellow, Department of Economy and Law, University of Cassino and Southern Lazio.

Correspondence concerning this article should be addressed to Andrea Moretta Tartaglione, Via Sant'Angelo Loc. Folcara snc, 03043, Cassino (FR), Italy. E-mail: a.moretta@unicas.it.
} 
both competitive and sustainable.

The identification of the correct approach to territory is not immediately describable because of its definition, its integration with economic activity, and the complex networks that directly and indirectly arise between places and stakeholders. It is not a simple matter to standardize a strategy of territory development, or to generate an ideal model of "relationship-wise connections" that encourage an active style between the territorial government body and the stakeholders that interact with the development policy.

In the 1980s, with the crisis in the manufacturing sector, researchers' consideration of topics ascribable to place-marketing was occasioned by the arrival of new economic scenarios and the growing globalization of the contexts: These phenomenon have inspired a need to know the on-going changes and have induced much thought about new approaches to place development and social development, including through multidisciplinary logics.

The object of place-marketing is represented by the place - a public good - and so its aims are a "public asset", namely, the creation of value for socialization (Moore, 1995) and to improve the quality of life of the citizens and the main stakeholder. ${ }^{1}$

The studies of authors who have, over time, dealt with place-marketing can be divided into different currents: Some show an approach referred to as the "pure" promotion of so-called urban facilities (Ave, 1993; Borchert, 1994); others attempt an approach that is mostly linked to strategic planning (Ashworth \& Voogd, 1990; Kotler, Haider, \& Rein, 1993). The main difficulties have appeared in the study of the similarities and the significant differences between place-marketing and business marketing. Authors like Flipo and Texier (1992) and Caroli $(1999,2006)$ have presented their contributions from this perspective. Among them, Corsico (1994) correlated marketing, strategies, and cities by considering several approaches; Ancarani and Valdani (2000), together with Camagni (1996) and Latusi (2002), have considered the possibility of thinking of the territory as a firm, studying its limits in terms of identification. The development of this notion has led to the interpretation of the place as a changeable reality, complex to decode, identifiable as a subject, and possibly manageable "as a firm." 2

Among the main research currents we find the relationship between stakeholder territorial government bodies, funds for the strategic planning of territories according to the sustainability principle, and the place-brand issue.

\section{Relationship Between Place-Brand, Network Planning, and Marketing Strategies: Focus on the Reference Literature}

Practical experience and critical reflection on the literature show a tendency to conceive and define the territories through certain identifying patterns. In some cases, we can identify a "local label"—a place

\footnotetext{
1 The issue of quality of life is considered fundamental in economic, social, and political studies. It is very important for the development of the community and, in general, of populations, and it arises especially in cities, which are the centre of life and of people's interests. Many economic and social indicators contribute to the measurement of the quality of life and many of them are also hard to identify. They include social inequality, access to different educational levels, pollution, safety and the perception of safety, political freedom, democracy, average salaries, the urban environment, the typology of city services, beauty of the landscape, and so on.

${ }_{2}^{2}$ The concept was promoted by Van den Berg in 1990. In 1994, Van den Berg and Van der Meer asserted that strategic place-marketing cannot be compared to the marketing of large firms, because the management of a city considerably differs from the management of a firm.
} 
image $^{3}$ - as a result of a common language and experience of the stakeholders, without defining a specific location. In these cases, the territorial governance must choose whether to allow the spontaneous evolution-or devolution - of the positioning elements to an entity rationalized in a brand, or to drive strategically a place-brand project through a structured marketing-oriented plan.

The concept of place-brand has, in recent years, received increasing attention among scholars, who have focused on the concepts of management, looking for cooperation, development of knowledge, and sharing of strategic planning models inspired by the core concepts of marketing. Among the most significant work of systematization of the reference literature on place-brand, we mention the research of Ashworth and Kavaratzis, (2010), Hankinson (2004), and Kavaratzis and Ashworth (2005), and we consider the contributions of Anholt (2007) to the competitiveness of nations, cities, and regions in relation to the image perceived by stakeholders and studies of specific performance indicators. Medway and Warnaby (2008) have addressed the issue from another perspective; specifically, they have examined the relevance to marketing of images perceived in negative territory (cities, provinces, different places), which over time have gained notoriety due to adverse events. These authors have also suggested the use of levers of communication due to demarketing. Medway and Warnaby, in the case study cited, also speak of "perverse place-marketing" which supports the possibility of identifying benefits of the appropriate dissemination of the negativity of a place - or rather, of the less attractive characteristics (unpleasant events, massacres, catastrophes, features which are not positive stakeholders or people), identifying the so-called negative place image. This hypothesis helps to support the argument that the management of a place image (whether negative or positive) can be defined as a place-brand that, over time, will generate value for stakeholders.

Hankinson (2004), Kavaratzis and Ashworth (2005) systematized the contributions of many authors arguing that the sites can be conceptualized as recognizable brands and that, above all, they can be powered by a defined target group, classified in the work of Kotler et al. (1993). In this case, we speak of visitors, workers, residents, and businesses. ${ }^{4}$

Depending on the territory under analysis, we can see the different desires and needs of specific groups that can help to strengthen the relevance of the distinguishing features of the territory; the larger the target group, the greater the number of relevant factors that multiply the difficulty of identifying a distinct and recognizable image. Also, the larger the territory, the more distinctive elements, characteristics, variability, and the number of target groups, and this causes difficulties in building brand awareness according to the principles emerging from naturally generated positioning, or built in some way through actions initiated on the specific territory or otherwise especially valued. ${ }^{5}$

A major strand in studies of place management, receiving special interest from scholars, is destination branding: in particular, relational elements, marketing policies, and the evolutionary dynamics between tourism destinations and recipient-tourists, players that over time can build the destination brand. Among the authors

\footnotetext{
${ }^{3}$ Work in terms of place brand, country image, and brand positioning, though similar, are addressed with different approaches on the international level. The literature indicated below identifies the place image as a spontaneous image, which is overall created in the mind of the person concerned to the territory - that is, the set of identity and experience in the area.

${ }^{4}$ Regarding the variation proposed by Kotler et al. (1993), it is possible to specify the classification as in Hankinson (2004), who divided the category of visitors into leisure tourists and business travelers, or as in Zenker and Petersen (2009), who talked about interior and potential residents. In the latter are to be placed students and members of the creative class.

${ }^{5}$ In the case of large areas, the development of a place-brand implies a communication campaign aimed at both inside and outside to share the mission and vision and to support the joint work of the actors of marketing planning.
} 
who have examined this subject are Morgan and Pritchard (2004), Pencarelli and Gregori (2009), and Pencarelli and Splendiani (2010).

The territorial model of reference for the place-brand can be identified in the city, ${ }^{6}$ which, with due caution, can partially attenuate the complex problem of the definition of territorial boundaries; ${ }^{7}$ talking about place-brand for a large area is complex, especially if you try to go beyond the concept of administrative boundaries, as a territory, like a network, should not be subject to border schematics, but should define itself in a geographical space and be confined to a specific course of work relations that arise between the subjects of the local community, stakeholders and, especially, businesses. A place-brand would be identified as the synthesis of place-marketing strategies and would represent the objectives of the community and of the strategic place-marketing plan. The studies mentioned above help to support the hypothesis that a territory is more likely to affirm a defined positioning of its place-brand, if it can optimize and improve its place image, avoiding leaving the construction of a specific image to spontaneous events.

Hankinson (2004) focused on the importance of research-behavior relationships between stakeholders and the consistency between worlds and attributes evoked by the brand and specific territorial reality. By identifying three elements with the term "core brand" (namely, personality, positioning, and reality), he defined place identity (see Figure 1), which is the "core" of the place-brand. The latter is built and strengthened over time only if the identity has those items in it.

The primary elements that Hankinson described in the "core brand" that define place identity are: the "personality", which identifies the potential attributes of the territory (functional, symbolic, and experiential attributes); the "positioning", which would identify specifically the "place positioning" or attributes that, naturally and not systematically, make the area unique, along with the basic elements common to other areas; and the "reality", which identifies the level of consistency between what the image of the territory promises and what the observing subject can find in the area.

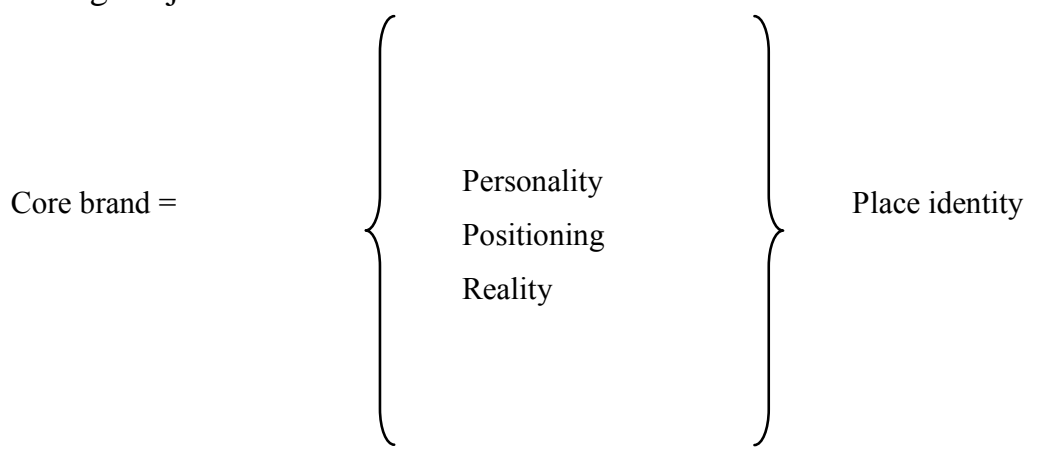

Figure 1. Core brand and place identity. Source: Hankinson (2004).

We can see the importance of making coherent what is communicated with what actually exists in the territory; this concept and its importance are also mentioned by Allen (2007), who emphasized the need for consistency between theory, marketing planning, communication, and the result in the territory.

Figure 2 summarizes the ideas of Hankinson (2004) on the importance of relationships between

\footnotetext{
${ }^{6}$ Consider the cases of Manchester, Liverpool, Madrid, Barcelona, etc..

7 Caldwell and Freire (2004) say that "The factors that influence the image of a country are different from the factors that affect a region and city. In this sense, the work of branding a country is different from that of branding a region or city".
} 
stakeholders and the consistency in behavior between worlds and attributes evoked by the brand and the specific territorial reality. The quality of the relationship in the network (see Figure 2) and the classification of each element in the primary "core brand" (personality, positioning, and reality) are strictly connected to the nature and quality of relationships and the attitude to stakeholder collaboration with the local administrators. In this paper, we add two important elements:

- The governing body's ability to plan, coordinate, and implement a marketing strategy, possibly in bottom-up mode, involving many stakeholders and building strong and durable relationships;

- The willingness of stakeholders to observe the marketing strategy for long periods of time, extending the assertion of a shared strategic positioning, rather than framing the place offer in an image resulting from a set of uncoordinated inputs.

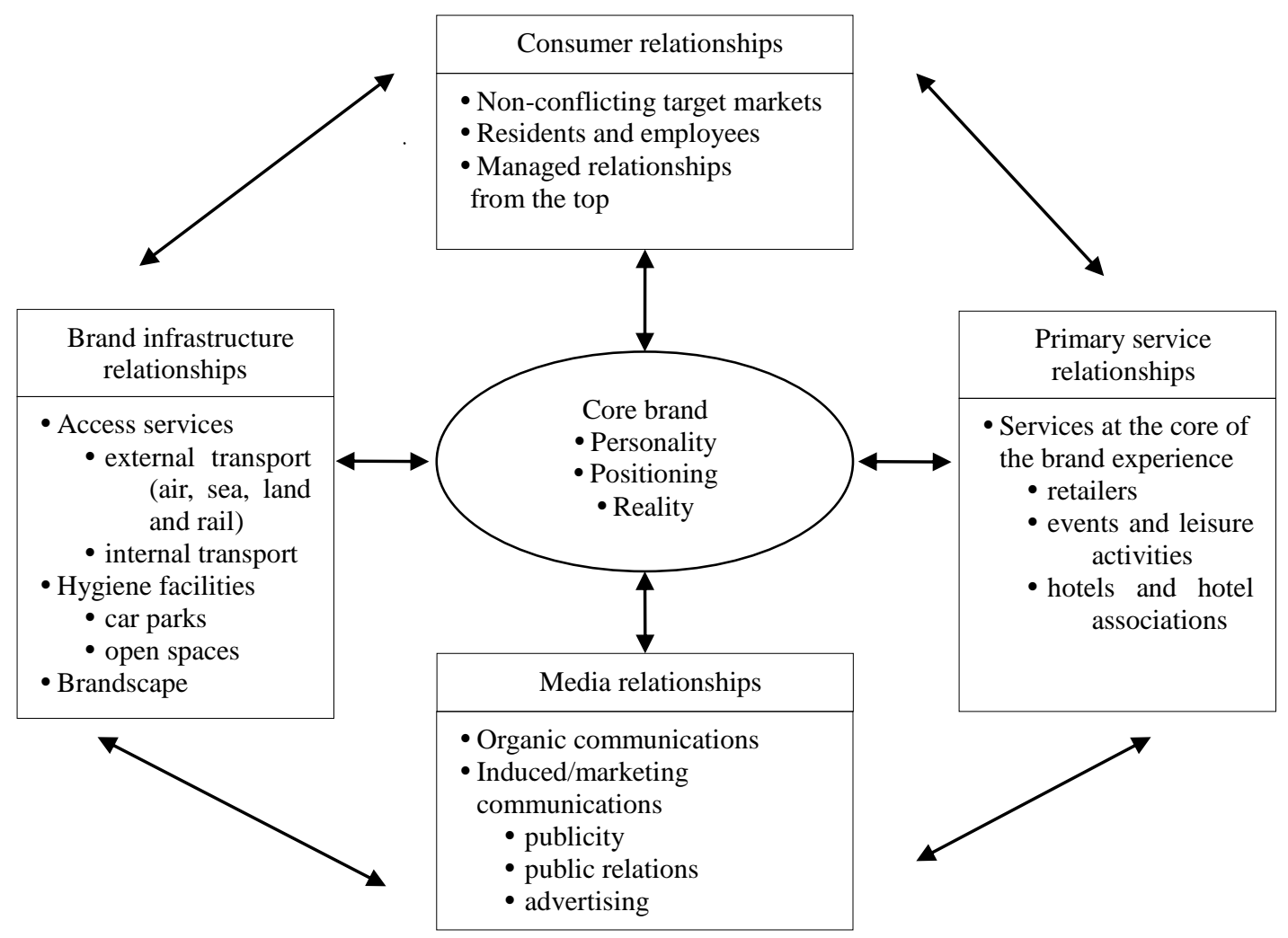

Figure 2. Relational network brands: Towards a conceptual model of place-brands. Source: Hankinson (2004).

A brand stands out from its competitors by its specific positioning and its personality, which corresponds to a unique combination of functional attributes and symbolic values (Hankinson \& Cowking, 1993). A brand incorporates a set of beliefs and physical and sociopsychological attributes associated with the product (Simoes $\&$ Dibb, 2001): The branding implies a conscious and deliberate process in which such attributes are selected and combined to add value to the products and services (Knox \& Bickerton, 2003). Thinking from the perspective of place-branding means identifying a country, region, or province as a multidimensional construct characterized by the strategic functional, relational, and emotional elements that society creates in the public mind as a single set of associations with the place - in the "consumer's mind". In this sense, branding means to identify the positioning of the territorial area, to define attributes, and to assign values in the present and the 
mission and vision in the future.

Although the debate is still rich in ideas, it is argued in this paper that the place-brand is not a static or defined construct; it is rather the synthesis of a place image consistent with the strategic positioning identified in the relational network among stakeholders, services, infrastructures, and projects, valued and systematized in a place-marketing strategy.

The place-brand assumes a key role in both communications directed to the outside of the territory and that aimed inside the area, in line with the constitutive components of the brand (Howard, 1977; Busacca, 1994, 2000). In the case of external communication, the place-brand plays a role in identifying, comparing, and generating confidence: In the process of identifying, the place-brand aims to convey the image of the area and its distinctive features. In the case of comparing, the role of the place-brand is to signal, directly or indirectly, the particular differences between the represented territory and other territories. Finally, the place-brand's role of generating confidence allows it to appear as the guarantor of the activities and results of marketing planning in the area, as well as the correspondence between the "promise" of marketing and the territorial reality. In the second case, communication with the interior of the area has a function addressed to stakeholders - as communicating a common identity will tend to enhance the aggregation operators - and one of coordination and support to define and develop the criteria for the use of the brand by involved people.

\section{Interactions Between Relevant Factors in the Definition and Affirmation of Place-Brand Positioning}

In the early 1980s, Ries and Trout (1981) declared that "The positioning is the conception of a product and its image in order to give him, in front of the consumer, a location appreciated and different from that occupied by the competition". The reference literature in the field of marketing and branding is unanimous in considering that there are several issues to be addressed in the field of product positioning, ${ }^{8}$ businesses, and brands. Here we consider the distinctive characteristics; the perception that consumer clusters have of the product's, company's, or brand's competitors; the optimum position for a good chance of survival in the market; and the marketing tools available to the budget.

Borrowing concepts from the theory of marketing businesses, we can frame similarities between the processes of identifying place-brand positioning and firm-brand positioning: There are elements in the process of analysis of the strategic positioning of the territorial brand that cannot be underestimated.

The territory as "subject" or "viable system" will have an ultimate survival aim over time under conditions guaranteed by sustainable development. In this sense, the territory will survive, albeit changing according to specific strategic directions towards different local communities that take turns characterizing and placing the image and its material and immaterial reality.

Since the territory, regardless of administrative boundaries, is a complex system with components in continuous interaction, it generates (quite independently of any marketing strategy) communication signals and impulses inward and outward (place identity) that rapidly and continuously stimulate the perception of observers. Although the outward impulses may be continuous, multiple observers are characterized by different cognitive facilities and varied interests and are stimulated by the territory in different ways. Thus different "place images" will be generated. The indirect signals coming from place, regardless of the governing body,

\footnotetext{
${ }^{8}$ Wind (1982) identified six types of brand positioning based on the distinctive quality of the product, the benefits found in the product, brand, or company, the occasion of use, the user category, the product category, and its distinctiveness in the market.
} 
will express their meaning in the scheme of the core brand of Hankinson, and can be identified with the place identity that is characterized by the subjective impressions of the observer who sees generate a specific mental place image?

In summary, the place identity is the "core brand" identified by Hankinson and, in the place identity, the "place positioning" can be identified through the affirmation (the automatic and non-systemic strategy of development) of some of the places' features that in some way objectively make it unique and recognizable. When this system of automatic definition of the impressions includes the work of a government able to successfully implement a place-marketing strategy, a place image can be transformed in a strategic positioning identified with the place-brand positioning. The place-brand positioning is related to several factors that can enhance or degrade its essence depending on the degree of intensity of the effects they have on the observing subject - but also depending on the combinations that develop both independently and through plans. The basis of the place-brand positioning is made up of levels of recognition and affirmation of the distinguishing characteristics of the place and the efficiency of the marketing strategy. The roles of time, of the quality of relationships between stakeholders, and of the size of the geographical and administrative area are then mutually dependent generators of influence, whether positive or negative.

The recognition and affirmation of the distinctive features of the area-and therefore the affirmation of its place-brand positioning - depend on the consistency between the marketing strategy and the reality actually found in the territory - which implies a situation of excellence among the relations in the network of local stakeholders. ${ }^{10}$ In Figure 3, we show a simulation of the effects in the case of verified coherence (the dashed line) and in the opposite case (the solid line). ${ }^{11}$ Putting the play time on the $x$-axis and the levels of minimum, average, and maximum levels of affirmation of the distinguishing characteristics of the area on the $y$-axis, we represent functions that allow the simulation of the situations described above.

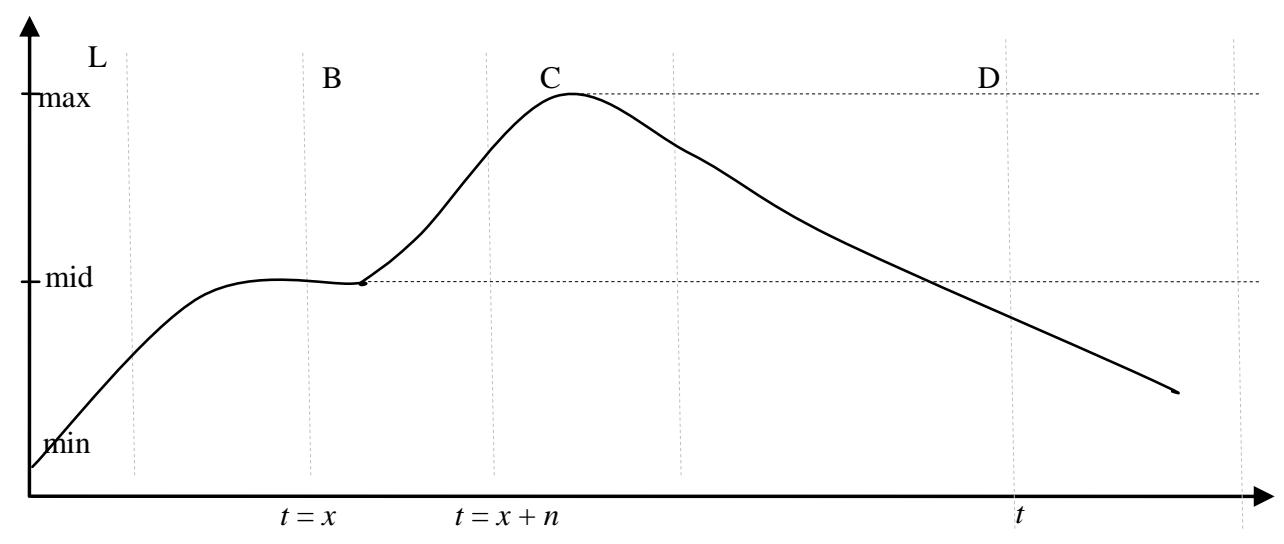

Figure 3. Relationship between level of success of the distinctive features of the area (principal assets), the time factor ( $t$ ), and contribution of the marketing strategy. $t=$ identifies the time on the $x$-axis.

\footnotetext{
9 The subjective expression that the area gives to observers who come into contact with the place identity is called the "place image".

${ }^{10}$ If the operational policies underlying a good place-marketing strategy are consistent with the reality that is found in the territory (that is, if what the marketing promises to the consumer is to be found in the area), it will receive the highest level of recognition and affirmation of the distinctive features of the territory.

11 A good positioning must be secured to a corresponding physical reality in the territory which equals the expectations of the target audience and helps to define the same position (Morgan, Pritchard, \& Piggott, 2002).
} 
In Figure 3, L represents the level of success of the distinctive features of the territory. From a minimum level of success, the maximum level (point C Max Level) may be reached through a place-marketing strategy. In the event that marketing strategies are not developed, the level of affirmation of the distinctive features stands, in a natural way variable from territory to territory, around an average value given by the natural perception of the distinguishing emerging features. Under the reported conditions, for periods of time greater than $t=x$, the statement and the "reputation" of the distinctive features, if not reduced, stand at a medium level.

Between B and C: The solid line expresses the results of increased awareness of the distinctive characteristics following the implementation of a marketing strategy for success. This is the case in which there is consistency between the marketing promise and the real organization and setting of the place. Without a marketing strategy, in the same period, the result shown by the dotted line would be obtained.

Between $\mathrm{C}$ and D: The solid line indicates the range in which the influence of time-and therefore the noncompliance in the long term of the marketing strategy—or of the difficulties arising from the large size of the territory act to lower the statement of distinctive features and weaken relations between stakeholders. Although we can achieve a maximum level of recognition of the distinctive characteristics, we may incur a progressive weakening of the same due to the factors previously mentioned. In some cases, however, it is possible to encounter maintenance over time (and sometimes also an increase) in the level of affirmation of the distinctive features: This is indicated by the dotted line that starts from $\mathrm{C}$ and proceeds horizontally. In the final situation, the stakeholders are aligned in a single marketing strategy and excellence exists in the relations between them.

Analyzing the graph of Figure 3, it can be seen that:

- All the elements of the place-brand management are in relation to time, which contributes to weaken the marketing strategy, the exclusivity of distinctive features, and the relations between stakeholders;

- The quality of relations among stakeholders in the process of place-brand positioning is relevant, and it contributes to define the place-brand's distinctive features.

It could be possible to analyze the relations among place-brand positioning (PBP), the size of the territory (VT), and marketing strategy. In particular, because the PBP depends on place image (PI) and marketing strategy (SM), the size of the place (VT) could be analyzed as a divisor of the relevance of the PI. Only marketing strategy could then serve as a multiplier. We can represent the concept as follows:

$$
P B P=(P I / V T) \cdot S M
$$

From this expression, we outline the major differences that explain meanings that are apparently similar but, especially for the area, are in close collaboration with the marketing strategy and the size of the affected area.

The place-brand positioning (PBP) is therefore the result of a perceived place image: It is sensitive to the size of the territory (the larger the size, the more possible interactions between stakeholders decrease) and is enhanced (or weakened) through a marketing strategy capable of facilitating the transition from the place image to the place-brand positioning by the launch process of generating value.

In this sense, Table 1 represents the path of construction of place-brand positioning, beginning from the recognition of a generic place image of the area-that is, the spontaneous overall image that is created in the mind of a person thinking of the territory, regardless of the strategic marketing intervention. The positioning is generated through the emergence of distinctive features and the place-marketing strategy. 
Table 1

From Place to Place-Image Brand Positioning

\begin{tabular}{|l|l|l|}
\hline Construct & \multirow{5}{*}{ Place image } & Elements of generation of the construct \\
\hline \multirow{3}{*}{ Place-brand positioning } & Generated by & $\begin{array}{l}\text { Asset and drivers: tangible and intangible } \\
\text { distinctive features }\end{array}$ \\
Place-brand positioning & $\begin{array}{l}\text { Asset and drivers (tangible and intangible), affirmation of distinctive } \\
\text { features, and territorial marketing strategy }\end{array}$ \\
\hline
\end{tabular}

Note. Source: Authors' work.

\section{Importance of the Relational Network and the Bottom-up Approach in Place-Brand Strategy}

The importance of networking between local actors and government bodies concerned with the development of the territory with a view to marketing has been studied by Simoni (2009), among other authors. Specifically, this author, taking a page from Golinelli and Dezi (1997), summarizes the need to identify the degree of centrality and the clustering coefficient of the territorial network in order to measure the number and the strength of relationships between the actors involved in the network and the bodies in the central location. For radical interventions in place positioning, the role of a single body with a central position is more efficient; for less radical interventions, a greater number of central bodies may be efficient in a network with an average relational intensity. It remains clear that the spontaneous involvement of more actors-for example, through a bottom-up model-may lead to an increased quality of relationships in the network, and an affirmation and strengthening of the effects of interventions over the longer period, but also implies greater attention and preparation of local actors. The connection between local actors and the relevant assets and drivers systematized in a place-marketing strategy can be generated in different ways, ${ }^{12}$ and the governing body as the "director" of the development is important, though not essential at the beginning of the project. In some cases, place-marketing projects are proposed by local government bodies, which in most cases are identified with public bodies (municipalities, provinces, regions, etc.); in other situations, it is one or more investors who initiate a project to develop the area with the intention of promoting the economic development of their sector of activity. In several cases, however, the approach is bottom-up, and is created by a group of subjects in the territory, giving rise to individual initiatives, ensuring that central government is stimulated to support the definition of an overall marketing strategy. ${ }^{13}$

In several reported cases, it has not always been possible to identify specific expertise-whether these

\footnotetext{
12 Stokes (2008) presented three models: the top down, in which a few stakeholders, through one or two public entities, take the lead and guide the development process with the aim of optimizing the return on investment; the mixed model, in which many stakeholders together with a public entity drive the strategic process, seeking a balance between the private need for economic return and the will to develop the local economy in the public interest; the third model is independent of the proponent, but is characterized by the will to obtain the maximum involvement of local actors and a return linked to sustainable development with high social benefits.

13 Among the problems studied in the framework of place-marketing, there are several emerging complexities, such as:

(1) The classification of the fields of definition of the territory to be investigated, such as city, region, nation, spatial area without administrative boundaries, and so on;

(2) Identification of those responsible for the initiation and implementation of a marketing strategy, in which case there are several techniques applicable to each aspect, whether spatial, cultural, business features, and the available financial resources.
} 
private individuals, different investors, businesses combinations, or the governments of local authorities - resulting consequently in a critical level that threatens the projects in progress and undermines the relational levels between actors. In such cases, bottom-up initiatives would seem to give better results in the long run, both in terms of implementing the marketing strategy, and, in general, the effectiveness of the network of local actors - think, for example, of the tools of negotiated planning. ${ }^{14}$

The greatest opportunities for a bottom-up approach ${ }^{15}$ are found by internalizing the metaphor of the territory as a "subject" (Camagni, 1996; Caroli, 2006) with vitality, interactivity, and development capability; the territorial "subject" is able to self-determine the importance of the network elements, the nature and characteristics of its governing body ${ }^{16}$ which has been democratically elected by residents and internal stakeholders, and its governing body is the expression of a public authority or multiple mutually associated administrations; ${ }^{17}$ in contrast, an area identified as a "complex" product, or as an entity to organize and "sell", would have less autonomy arising "from below" and reduced participatory planning. In the case of top-down interventions, however, even in a territory "subject", organizational shocks and difficulties would be experience in the network among those stakeholders who might in some way suffer from higher levels of rigidity. In some cases, however, over shorter times, good results might be obtained from the transformation of territories. In any case, it is necessary to evaluate the result and the conditions for sustainable development. ${ }^{18}$ Generally, the bottom-up approach can reach a good solution of centrality of the primary stakeholders (companies and people), and through this approach, civil society can become involved in development projects with direct impact on the local environment. However, there are difficulties and strengths to this. The following elements show the complexity of bottom-up projects:

- The need to commit long periods of time to generate interest in the subjects that are to be involved;

- The need to find a large number of supporters of the project and to carry out widespread initiatives;

- The need to manage the early stages of negotiations and meetings for the sharing of guidelines and directives;

- The need to develop different projects regarding the expectations of the individual because of compatibility with certain types of financing.

Among the strengths are:

- The shared ownership of a variety of businesses and individuals;

- More opportunities to produce more efficient interactions within different kinds of networks due to

\footnotetext{
14 Agreement program, project framework, territorial pact, program contract, framework contract, and PIT, are all projects for the development of the area that are relevant to the negotiated programming.

15 Among the authors who have reported opportunities and problems as part of the territory in the bottom-up and top-down views are Zanderighi (2004) and Stokes (2008).

${ }^{16}$ In this case, consider any area of land ruled by a government democratically elected by the population of a territory. The governing body will be the expression of the strategic territory and will interpret the needs, including the developmental needs, of the stakeholders in a sustainable development perspective.

17 Some territories may, however, delegate the responsibility of marketing planning to public-private entities, and in some cases, the integrated efforts of several public entities may materialize in the planning and marketing of large, integrated areas. Consider here the initiative of Trentino SpA: http://www.trentinospa.info/interne/societ\%C3\%A0_interna.ashx?id=19843\&l=1.

18 Through a series of elements and top-down actions, a local identity is constructed; large events, road shows, and panel discussions are organized. Remote areas are promoted at trade fairs, inviting tourists and stakeholders to visit. But sometimes, as with the Province of Frosinone in 2010 (http://www.provincia.fr.it/showcontent.aspx $? 11=14 \& 12=149 \& 13=174$ ), the design and launch of regional labels or aggregation initiatives are done without proposals of content or services to be conveyed to the operators, who, in turn, are often insufficiently aware of the initiatives pertaining to them. In these cases, the initiatives remain a mere exercise in style and an instrument of political propaganda.
} 
the sharing of the "bottom-up" project and, therefore, more opportunities to develop a shared project in larger territories;

- The development of small systems of interacting and cohesive stakeholders, capable of providing a significant contribution to the development of the area;

- The possibility of having thorough knowledge of the territory and internal relations;

- The sharing of marketing communications and the subsequent spread of the place-brand image among stakeholders;

- The sharing and amplification at the capillary level of the guiding principles of the marketing strategy;

- Consistency between "top" planning and the reflected actual operations on the "bottom".

The top-down approach is certainly more immediate and linear, as it chiefly involves one or a few decision makers involved in the area. It represents advantages in creating projects: Initiatives planned and funded as part of the project are immediately, implemented thanks to the certainty of the funding sources; participatory planning processes are also resolved quickly, because of the low number of financiers. Of course, similar projects sometimes face resistance from some local stakeholders and this may contribute to the slowing of the process of generating a positive impact on the development project $^{19}$ in the case of the absence of a relevant involvement.

\section{Managerial Implications}

The ideas of this study lead us to consider the issue of the place-brand according to an approach that goes beyond the mere identification of a graphic symbol. In recent years, the experience of the practitioner has reduced the place-brand to a mere exercise to use for communication purposes, for limited periods, or even only in some promotional events. Several times in the initiatives proposed by policy makers at all levels, especially in Italy, we have seen a reduced ability to fill the place-brand with contents, to communicate the features to the primary stakeholders, and to see the potential of the land for various reasons-for example, a lack of ability to identify the real intangible value of the brand has become apparent. Place management plays a key role in leading the country from a generic image to a suitable place-brand positioning that will govern and control through a marketing plan and a shared strategy that are implemented daily by local actors; the role of territorial management is also relevant in the involvement of local actors themselves and in reinforcing the relations between them, in order to create and strengthen the value and nature of the place-brand (including through applying stimulus to bottom-up approaches). In this sense, in each region, the quality of management, culture, traditions, and respect for a marketing strategy, as well as the knowledge spread among the local actors and the principle of sharing of problems and opportunities, all determine the time resistance of the projects of place-brand.

In an evolutionary perspective, new areas of research are emerging: the analysis of the correspondence in time between declarations of intent to collaborate and effective collaboration; the open issues between the different levels of regional governance; the role of new technologies and the growing importance of the latter as a key asset in the economic development of the territories; the study of control systems of strategies, and the formulation of performance indicators for measuring the relationships between stakeholders.

\footnotetext{
${ }^{19}$ Examples and literatures on a top-down approach can be identified in works that link place development to investment by private or public-private partnerships. Examples include case studies of the relationship between land development and events (Wood, 2004; Allen, 2000; Hall, 1989, 1992; Hiller, 2000).
} 


\section{References}

Aiello, G., \& Donvito, R. (2007). The evolution of place marketing network and investment attraction (L'evoluzione dei network per il marketing territoriale e l'attrazione degli investimenti). MERCATI E COMPETITIVITÀ, 1, 49-70.

Allen, G. (2000). Event planning: The ultimate guide to successful meetings, corporate events, fundraising galas, conferences, conventions, incentives and other special events. Toronto: Wiley.

Allen, G. (2007). Place branding: New tools for economic development. Design Management Review, 18, 60-68.

Ancarani, F., \& Valdani, E. (2000). Place marketing strategies (Strategie di marketing del territorio). Milano: Egea.

Anholt, S. (2007). Competitive identity: The branding of nations, cities, regions (L'identità competitive: Il branding di nazioni, città, regioni). Milano: Egea.

Ashworth, G. J., \& Kavaratzis, M. (2010). Towards effective place brand management: Branding European cities and regions. Cheltenham, UK: Edward Elgar Publishers.

Ashworth, G. J., \& Voogd, H. (1990). Selling the city. London: Belhaven.

Ave, G. (1993). Urban marketing in Europe in urban planning and strategic urban marketing in Europe. Turin: Torino Incontra.

Borchert, J. G. (1994). Urban marketing: A review. In G. O. Braun, J. Karn, H. Linemann, A. Schultz, \& J. Woosnam (Eds.), Managing marketing of urban development and urban life. Berlin: Deitrich Reimer Verlag.

Busacca, B. (1994). Fidelity assets of the firms (Le risorse di fiducia dell'impresa). Torino: Utet.

Busacca, B. (2000). The brand value between postfordism and digital economy (Il valore della marca tra postfordismo ed economia digitale). Milano: Egea.

Caldwell, N., \& Freire, J. (2004). The differences between branding a country, a region and a city: Applying the brand box model. Journal of Brand Management, 12(1), 50-59.

Camagni, R. (1996). Economy and planning of sustainable cities (Economia e Pianificazione della Città Sostenibile). Bologna: Il Mulino.

Caroli, M. G. (1999). Place marketing (Il marketing territoriale). Milano: Franco Angeli.

Caroli, M. G. (2006). Place marketing: Strategies for sustainable competitive of the place (Il marketing territoriale: Strategie per la competitività sostenibile del territorio). Milano: FrancoAngeli.

Cercola, R., Bonetti, E., \& Simoni, M. (2009). Marketing and territorial strategies (Marketing e strategie territoriali). Milano: Egea.

Corsico, F. (1994). Urban marketing, tool for cities and companies, a condition for real estate development, a challenge for urban planning (Marketing urbano, uno strumento per le città e le imprese, una condizione per lo sviluppo immobiliare, una sfida per la pianificazione urbanistica). In G. Ave, \& F. Corsico (Eds.), Urban marketing (Marketing urbano in Europa). Torino: Edizioni Torino Incontra.

Duffy, H. (1995). Competitive cities succeeding in the global economy. London: Spon.

Flipo, J. P., \& Texier, L. (1992). Place marketing: From theory to practice (Marketing territorial: de la pratique à la théorie). Revue Française du Marketing, 136, 41-52.

Golinelli, G. M., \& Dezi, L. (1997). Networks finance and projects (Reti Finanza e Progetti). Padova: CEDAM.

Hall, C. M. (1989). The definition and analysis of hallmark events. Geojournal, 19, 263-268.

Hall, C. M. (1992). Hallmark tourist events: Impact, management and planning. London: Belhaven.

Hankinson, G. (2004). Relational network brands: Towards a conceptual model of place brands. Journal of Vacation Marketing, 10(2), 109-121.

Hankinson, G., \& Cowking, P. (1993). Branding in action: Cases and strategies for profitable brand management. London: McGraw-Hill.

Hiller, H. (2000). Mega events, urban boosterinsm and growth strategies: An analysis of the objectives and legitimations of the Cape Town 2004 Olympic Bid. International Journal of Urban and Regional Research, 24(2), 439-458.

Howard, G. (1977). Consumer behavior: Application of a theory. New York: McGraw-Hill.

Jensen-Butler, C., Shacar, A., \& van Weesep, J. (1997). European cities in competition. Avebury: Aldershot.

Kavaratzis, M., \& Ashworth, G. J. (2005). City branding: An effective assertion of identity or a transitory marketing trick? Tijdschrift voor Economische en Sociale Geografie, 96(5), 506-514.

Knox, S., \& Bickerton, D. (2003). The six conventions of corporate branding. European Journal of Marketing, 37(7/8), 998-1016.

Kotler, P., Haider, D. H., \& Rein, I. (1993). Marketing places: Attracting investment, industry and tourism to cities, states and nations. New York: The Free Press. 
Latusi, S. (2002). Place marketing for investments (Marketing territoriale per gli investimenti). Milano: Egea.

Medway, D., \& Warnaby, G. (2008). Alternative perspectives on marketing and the place brand. European Journal of Marketing, 42, 641-653.

Moore, M. H. (1995). Creating public value: Strategic management in government. Cambridge, M.A.: Harvard University Press.

Morgan, N., \& Pritchard, A. (2004). Meeting the destination branding challenge. In N. Morgan, \& A. Pritchard (Eds.), Destination branding, creating the unique destination proposition. Butterworth-Heinemann, Oxford.

Morgan, N., Pritchard, A., \& Piggott, R. (2002). New Zealand 100\% pure: The creation of a powerful niche destination brand. Journal of Brand Management, 9, 335-354.

Paddison, R. (1993). City marketing, image reconstruction and urban regeneration. Urban Studies, 30(2), 339-350.

Pencarelli, T., \& Gregori, G. (2009). Communication and branding of touristic destinations (Comunicazione e branding delle destinazioni turistiche). Milano: Franco Angeli.

Pencarelli, T., \& Splendiani, S. (2010). Intangible assets in tourism: The role of destination branding (Risorse immateriali nel turismo: Il ruolo del destination brand). In L. Marchi, \& S. Marasca (Eds.), The intangible assets in companies economies (Le risorse immateriali nell'economia delle aziende). Il mulino, Bologna.

Ries, A., \& Trout, J. (1981). Positioning: The battle for your mind. New York: Warner Books-McGraw-Hill Inc..

Salminem, A. L. (2003). Governing networks. Amsterdam: IOS Press.

Sassen, S. (1997). The cities in the global economy (Le città nell'economia globale). Bologna: Il Mulino.

Simoes, C., \& Dibb, S. (2001). Rethinking the brand concept: New brand orientation. Corporate Communications: An International Journal, 6(4), 217-224.

Simoni, M. (2009). The territorial networks in the place marketing resource centered process (I network territoriali nel processo di marketing territorial resource centered). In R. Cercola, E. Bonetti, \& M. Simoni (Eds.), Marketing e strategie territoriali. Milano: Egea.

Stokes, R. (2008). Tourism strategy making: Insights to the events tourism domain. Tourism Management Ume, 29(2), $252-262$.

Van den Berg, L. (1990). Urban policy and market orientation. Euricur: Erasmus University Rotterdam.

Van den Berg, L., \& Braun, E. (1999). Urban competitiveness, marketing and the need for organizing capacity. Urban Studies, 36(5-6), 987-999.

Verlegh, P. W. J., \& Steenkamp, J. B. E. M. (1999). A review and meta-analysis of country of origin research. Journal of Economic Psychology, 20(5), 521-546.

Wind, Y. (1982). Product policy: Concepts, methods and strategy. Reading, M.A.: Addison-Wesley Publishing Co..

Zanderighi, L. (2004). Urban retail and new governance tools (Commercio Urbano e nuovi strumenti di governance). Milano: Il Sole 24 ore.

Zenker, S., \& Petersen, S. (2009). Resident-city identification: Translating the customer relationship management approach into place marketing theory. Proceedings from the 50th European Regional Science Association Congress. Jönköping, Sweden. 